\title{
High frequency of Fredrickson's phenotypes IV and IIb in Brazilians infected by human immunodeficiency virus Edilma MV Albuquerque ${ }^{1,2}$, Eliana C de Faria1,2, Helena CF Oliveira ${ }^{3}$, Daniela O Magro ${ }^{4}$ and Lucia N Castilho*1,2
}

\begin{abstract}
Address: ${ }^{1}$ Departamento de Patologia Clinica, Faculdade de Ciências Médicas, Universidade Estadual de Campinas- UNICAMP- Campinas, SP, Brazil, ${ }^{2}$ Núcleo de Medicina e Cirurgia Experimental, Faculdade de Ciências Médicas Universidade Estadual de Campinas- UNICAMP- Campinas, SP, Brazil, ${ }^{3}$ Departamento de Fisiologia e Biofísica, Instituto de Biologia, Universidade Estadual de Campinas- UNICAMP- Campinas, SP, Brazil and ${ }^{4}$ Departamento de Medicina Preventiva e Social, Faculdade de Ciências Médicas, Universidade Estadual de Campinas- UNICAMP- Campinas, SP, Brazil

Email: Edilma MV Albuquerque - edilmalbuquerque@gmail.com; Eliana C de Faria - cotta@fcm.unicamp.br;

Helena CF Oliveira - ho98@unicamp.br; Daniela O Magro - danimagro@terra.com.br; Lucia N Castilho* - nassi@fcm.unicamp.br

* Corresponding author
\end{abstract}

Published: I4 June 2005

BMC Infectious Diseases 2005, 5:47 doi:10.1 I86/147/-2334-5-47
Received: 09 March 2005

Accepted: 14 June 2005

This article is available from: http://www.biomedcentral.com/I47I-2334/5/47

(C) 2005 Albuquerque et al; licensee BioMed Central Ltd.

This is an Open Access article distributed under the terms of the Creative Commons Attribution License (http://creativecommons.org/licenses/by/2.0), which permits unrestricted use, distribution, and reproduction in any medium, provided the original work is properly cited.

\begin{abstract}
Background: Human immunodeficiency virus (HIV) infection is very prevalent in Brazil. HIV therapy has been recently associated with coronary heart disease (CHD). Dyslipidemia is a major risk factor for CHD that is frequently described in HIV positive patients, but very few studies have been conducted in Brazilian patients evaluating their lipid profiles.
\end{abstract}

Methods: In the present work, we evaluated the frequency and severity of dyslipidemia in 257 Brazilian HIV positive patients. Two hundred and thirty-eight (93\%) were submitted to antiretroviral therapy (224 treated with protease inhibitors plus nucleoside reverse transcriptase inhibitors, 14 treated only with the latter, 12 naive and 7 had no records of treatment).

The average time on drug treatment with antiretroviral therapy was 20 months. None of the patients was under lipid lowering drugs. Cholesterol, triglyceride, phospholipid and free fatty acids were determined by enzymatic colorimetric methods. Lipoprotein profile was estimated by the Friedewald formula and Fredrickson's phenotyping was obtained by serum electrophoresis on agarose. Apolipoprotein B and Al and lipoprotein "a" were measured by nephelometry.

Results: The Fredrickson phenotypes were: type IIb (5I\%), IV (4I\%), Ila (7\%). In addition one patient was type III and another type V. Thirty-three percent of all HIV+ patients presented serum cholesterol levels $\geq 200 \mathrm{mg} / \mathrm{dL}, 6 \mathrm{I} \% \mathrm{LDL}-$ cholesterol $\geq 100 \mathrm{mg} / \mathrm{dL}, 65 \%$ HDL-cholesterol below $40 \mathrm{mg} / \mathrm{dL}, 46 \%$ triglycerides $\geq 150 \mathrm{mg} / \mathrm{dL}$ and $10 \%$ have all these parameters above the limits. Eighty-six percent of patients had cholesterol/HDL-cholesterol ratio $\geq 3.5,22 \%$ increased lipoprotein "a", 79\% increased free fatty acids and $9 \%$ increased phospholipids. The treatment with protease inhibitors plus nucleoside reverse transcriptase inhibitors increased the levels of cholesterol and triglycerides in these patients when compared with naïve patients. The HDL-cholesterol $(p=0.01)$ and apolipoprotein Al $(p=0.02)$ levels were inversely correlated with the time of protease inhibitor therapy while total cholesterol levels had a trend to correlate with antiretroviral therapy $(p=0.09)$.

Conclusion: The highly varied and prevalent types of dyslipidemia found in Brazilian HIV positive patients on antiretroviral therapies indicate the urgent need for their early diagnosis, the identification of the risk factors for CHD and, when needed, the prompt intervention on their lifestyle and/or with drug treatment. 


\section{Background}

The prognosis of patients with acquired immune deficiency syndrome (AIDS) was so limited until recently, that the medical interest in other long term health problems was irrelevant. The potency and sustained efficacy of the highly active antiretroviral therapy (HAART) for treating these patients brought a profound positive impact on their life expectancy reducing their mortality rates from AIDS [1].

Several reports [1-10] described the worsening of coronary heart disease (CHD) and vascular atherosclerotic complications in HIV+ patients after HAART therapy. Recently, the DAD study (Data Collection on Adverse Events of Anti-HIV Drugs) showed an increase in the risk of myocardial infarction (MI) from $0.30 \%$ in patients with no antiretroviral therapy to $1.07 \%$ in patients receiving these therapies, over a 3 year period [10].

Dyslipidemia is a major risk factor for the development of CHD. It has also been reported that the AIDS infection itself is capable of inducing dyslipidemia [11-14].

Hypertriglyceridemia was the first finding to be reported in HIV-infected patients, but other lipid abnormalities have also been described such as hypocholesterolemia, hypobetalipoproteinemia, hypoalphalipoproteinemia and, more rarely, hypercholesterolemia $[11,13,15-17]$.

Brazil is the epicenter of the epidemic in South America and accounts for three-fifths of reported AIDS cases and 57\% in Latin America and Caribbean. Among the population of high risk the prevalence is $42 \%$ [18].

Up to now two local studies [14,19] explored the dyslipidemia of Brazilian HIV+ patients but both in a small number of cases.

Therefore the aim of this study was to determine the prevalence and severity of different types of dyslipidemia in a large local HIV+ Brazilian population using antiretroviral therapy. Serum lipids, lipoproteins and apolipoproteins were measured and the effects on them of the viral load, $\mathrm{CD} 4$ counting and duration of therapy were evaluated.

\section{Methods}

This study was approved by the Medical Ethics Committee of the Medical Sciences Faculty of the University of Campinas. Written consent was obtained from the patients or their relative for publication of study.

Two hundred and fifty seven HIV+ patients were enrolled in the protocol. They were attended in the Infectious Diseases Clinic at the University of Campinas. Sixty-two percent were men and $38 \%$ were women, with an average age of $35 \pm 8$ years, body weight average $67 \pm 13 \mathrm{Kg}$ and body mass indexes (BMI) $24 \pm 4 \mathrm{Kg} / \mathrm{m}^{2}$. Two hundred and thirty-eight $(93 \%)$ were submitted to antiretroviral therapy (224 treated with protease inhibitors plus nucleoside reverse transcriptase inhibitors, 14 treated only with the latter, 12 naïve and 7 had no records of treatment). The average time on drug treatment with protease inhibitors was 20 months (range 2 to 47 months). None of the patients was under lipid lowering drugs and any other disease was described in their records.

The measurements of fasting serum cholesterol (Chol), HDL-cholesterol (HDL-chol) and triglycerides (TG) were obtained by enzymatic colorimetric methods (automated Mega-Bayer system). The LDL-cholesterol (LDL-chol) and VLDL-cholesterol (VLDL-chol) were estimated by Friedewald's equation. In patients with triglyceride levels above $400 \mathrm{mg} / \mathrm{dL}(\mathrm{n}=16)$, Friedwald's equation was not used. The apolipoproteins A1 (Apo A1), B100 (Apo B) and lipoprotein "a" [Lp (a)] were measured by nephelometric methods (semi-automated Beckman Array-360 system) [20]. Free fatty acids (FFA) and phospholipids (PL) were determined by enzymatic colorimetric methods (Wako Chemicals $\mathrm{GmbH}$, Japan). The plasma lipoproteins were fractioned by agarose gel electrophoresis (Paragon Electrophoresis System - Beckman, Ca, USA). The bands were carefully analyzed by visual inspection [21]. Apo E genotyping was performed by PCR assay [21] in 3 cases suspected of type III phenotype.

In a sub-group of patients presenting Chol and/or TG, respectively equal to or above 200 and $150 \mathrm{mg} / \mathrm{dL}(\mathrm{n}=$ 141), the criterion for describing the dyslipidemia was in accord with WHO/ Fredrickson's classification [22].

The lipid profiles were analyzed using the values recommended by the National Cholesterol Education Program (NCEP, 2001) [23]. The desirable Chol/HDL-chol ratio was lower than $3.5[24]$ and was used as an CHD risk index.

The reference intervals for apolipoproteins, Lp (a), PL and FFA were obtained from the manufacturers' recommendations. Apo A1: 94-178 mg/dL and 101-199 mg/dL; Apo B100: $52-109 \mathrm{mg} / \mathrm{dL}$ and $40-103 \mathrm{mg} / \mathrm{dL}$ for men and women, respectively; $\mathrm{Lp}(\mathrm{a})$ below $30 \mathrm{mg} / \mathrm{dL}$; PL: 150-250 $\mathrm{mg} / \mathrm{dL}$ and FFA: 0.1-0.6 mEq/L.

Immunologic evaluation included measurements of lymphocyte sub-populations, CD4 and CD8, by flow citometry and the determination of the viral load by PCR.

Kruskal-Wallis with post test Dunn was employed to compare the lipidic parameter averages between the 2 groups of antiretroviral therapy users and between the treated 
Table I: Percentual distribution of HIV+ patients according to WHO/Fredrickson classification in total HIV+ patients.

\begin{tabular}{|c|c|c|}
\hline Type & Percent of dyslipidemic patients* $(n=103)$ & Percent of the total HIV+ population $(n=257)$ \\
\hline Ila & 7 & 3 \\
\hline Ilb & 51 & 20 \\
\hline III & 1 & 0,4 \\
\hline IV & 41 & 16 \\
\hline $\mathrm{V}$ & 1 & 0,4 \\
\hline
\end{tabular}

*Patients with chol and/or TG respectively, $>200$ and >150 mg/dL, were classified based on Fredrickson's classification

Table 2: Serum lipid, lipoprotein and apolipoprotein profiles in HIV+ patients $(n=257)$

\begin{tabular}{lccc}
\hline Variables $^{\mathrm{a}}$ & Mean \pm SD & Minimum & Maximum \\
\hline Chol & $185 \pm 55$ & 68 & 672 \\
TG & $192 \pm 179$ & 36 & 1512 \\
HDL-chol & $36 \pm 12$ & 12 & 73 \\
LDL-chol* & $112 \pm 38$ & 10 & 227 \\
VLDL-chol* & $31 \pm 16$ & 7 & 79 \\
PL & $192 \pm 72$ & 94 & 702 \\
FFA & $1.2 \pm 0.75$ & 0.10 & 6.3 \\
Apo Al & $121 \pm 28$ & 291 \\
Apo B & $88 \pm 26$ & 29 & 173 \\
LP(a) & $21 \pm 24$ & 37 & 124 \\
Chol/HDL-chol & $5.6 \pm 3$ & 1 & 39.5
\end{tabular}

aData expressed as $\mathrm{mg} / \mathrm{dL}$ and FFA as $\mathrm{mEq} / \mathrm{L} . * \mathrm{n}=24 \mathrm{I}$ patients

groups and naïve patients. Ancova and Pearson's tests were employed to correlate lipid profiles and CD4 cells, viral load and time of use of protease inhibitors. BMI, age and gender were chosen as covariates. Differences were considered significant when $\mathrm{p} \leq 0.05$.

\section{Results}

The patients were classified according to the Center for Disease Control (CDC) -1993 [25] as follows: stage A, $39.3 \%$; stage B, $12.4 \%$; stage C, $45.6 \%$ (44.0\% belonging to the clinical C3 category) and $2.7 \%$ were not clinically defined. There was an inversion of CD4 counting (average 337 cells $/ \mathrm{mm}^{3}$ ) and CD8 counting (average 947 cells/ $\mathrm{mm}^{3}$ ) that may be explained by the fact that approximately $44 \%$ of the patients belonged to the C3 category.

Forty-four percent of the patients who had their viral load measured presented less than 400 copies/mL, 29\% between $400-10,0000$ copies/mL and $27 \%$ above 10,000 copies/mL.
Fifty-five percent of total HIV+ population (141 patients) was selected by their high Chol and/or TG levels for further serum electrophoresis analysis. In eighteen patients the electrophoresis were not done and in 20 patients the results were inconclusive. The most frequent patterns according to Fredrickson's classification were type IV (41\%) and IIb (51\%) (Table 1). One patient was type III, another one type $\mathrm{V}$ and seven IIa.

Patients' lipid, lipoprotein and apolipoprotein profiles are reported in Table 2 . Figure 1 shows the percent distribution of HIV+ patients according to the NCEP (2001) classification [23]. Thirty-three percent of total HIV+ patients had Chol levels $\geq 200 \mathrm{mg} / \mathrm{dL}, 65 \%$ had HDL-chol below $40 \mathrm{mg} / \mathrm{dL}, 61 \%$ had LDL-chol $\geq 100 \mathrm{mg} / \mathrm{dL} ; 46 \%$ had triglycerides $\geq 150 \mathrm{mg} / \mathrm{dL}$ and $86 \%$ had the cholesterol/HDL-chol ratio $\geq 3.5$. Seventy-nine percent of the patients presented FFA values above the maximum reference value of $0.6 \mathrm{mEq} / \mathrm{L}$. The average serum concentration of PL and $\operatorname{Lp}(\mathrm{a})$ were within the reference limits. However, $22 \%$ of the patients had Lp(a) above $30 \mathrm{mg} / \mathrm{dL}$ and $9 \%$ had PL above $250 \mathrm{mg} / \mathrm{dL}$. 
Cholesterd

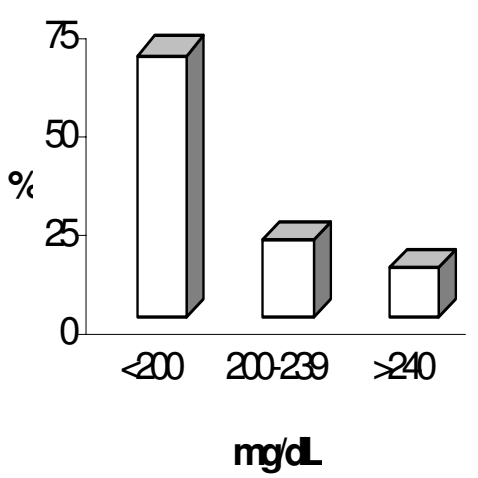

HD-cholesterd

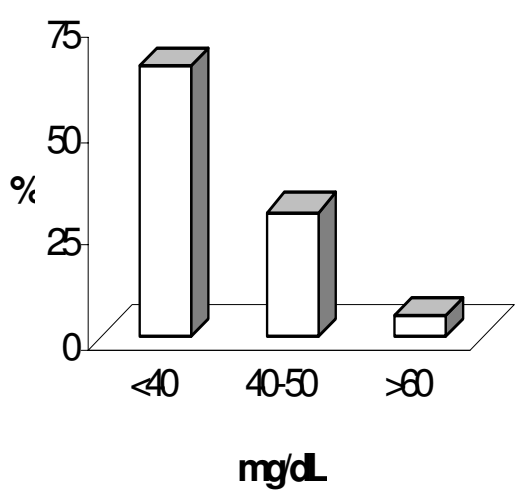

Total cholestero//R-cholesterd
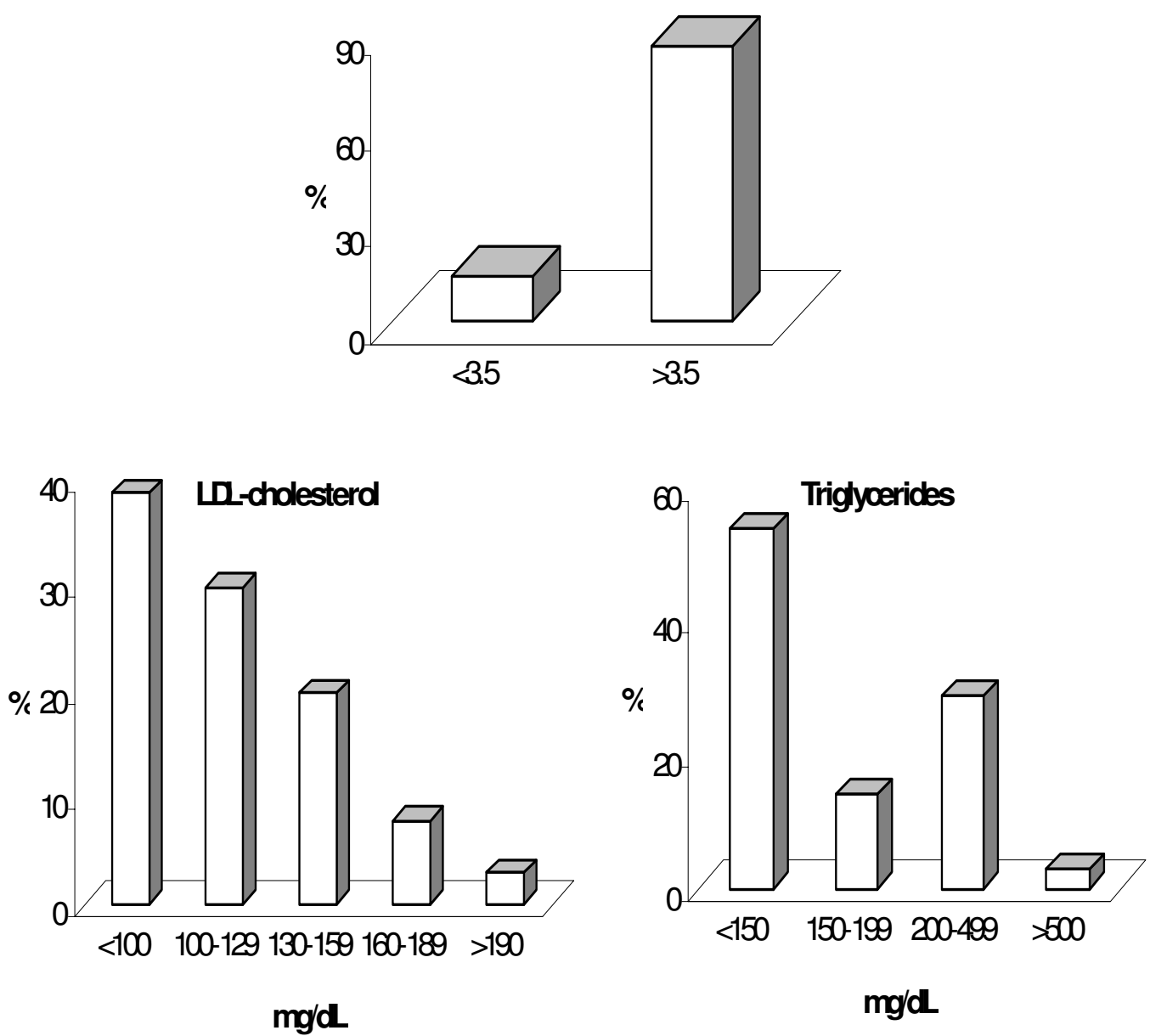

Figure I

Lipid frequency distribution patterns in HIV+ patients ( $n=236$ to 257 ) according to NCEP's recommendations. 
The mixed dyslipidemia in HIV+ patients are widely distributed and the frequency varied from 13\% for TG or Chol + LDL-chol + HDL-chol to 38\% for Chol+TG+HDLchol.

The treatment with protease inhibitors plus nucleoside reverse transcriptase inhibitors increased significantly Chol and TG levels $(\mathrm{p}<0.05)$ in these patients when compared to naïve HIV+ patients $(187 \pm 55 v s 150 \pm 21 \mathrm{mg} / \mathrm{dL}$ and $199 \pm 187 v s 106 \pm 51 \mathrm{mg} / \mathrm{dL}$ for Chol and TG, respectively), no differences were found between the two drugs groups.

There was a significant negative correlation (Figure 2) between the time of protease inhibitors (PI) therapy and HDL-chol $(\mathrm{r}=-0.214)$ and Apo A1 $(\mathrm{r}=-0.154)$ levels $(\mathrm{p}=$ 0.01 and $p=0.02$, respectively). Also a significant negative association ( $\mathrm{p}=0.03$ ) was found between Chol levels and the viral load. Total cholesterol levels have a trend to be associate with protease inhibitor therapy $(\mathrm{p}=0.09)$.

\section{Discussion}

Dyslipidemia using the WHO/Fredrickson classification in a Brazilian HIV+ patients is examined here for the first time.

Schmidt et al [25] described dyslipidemia in 57\% of 98 $\mathrm{HIV}+$ individuals treated with protease inhibitors and found a different prevalence from our group: phenotypes IV and V were more frequent than IIb and IIa. Maus et al [26] just recently presented this classification in 187 treated German HIV+ individuals. Some curious differences were found between the phenotyping of the 2 populations: types IIb and IV was equally frequent in our study, but the German group type IV was the predominant one.

The data presented here are alarming. A very high prevalence of different types of dyslipidemia was found in the population of $257 \mathrm{HIV}+$ patients: $33 \%$ showed increased cholesterol, $46 \%$ increased triglycerides, decreased HDLcholesterol level in $65 \%$, cholesterol/HDL-chol ratio $\geq 3.5$ in $86 \%$, increased LDL-cholesterol in $61 \%$, increased $\mathrm{Lp}$ (a) in $22 \%$, increased free fatty acids in $79 \%$ and increased phospholipids in $9 \%$. All of these profiles are strongly related to CHD risk.

In this study we showed that in patients using antiretroviral therapy there was an augment in the concentrations of plasma cholesterol and triglycerides when compared to naïve patients. We also found negative associations between the time on PI therapy and HDL-chol and Apo A1 levels and a trend to a positive correlation between the viral load and cholesterol levels.
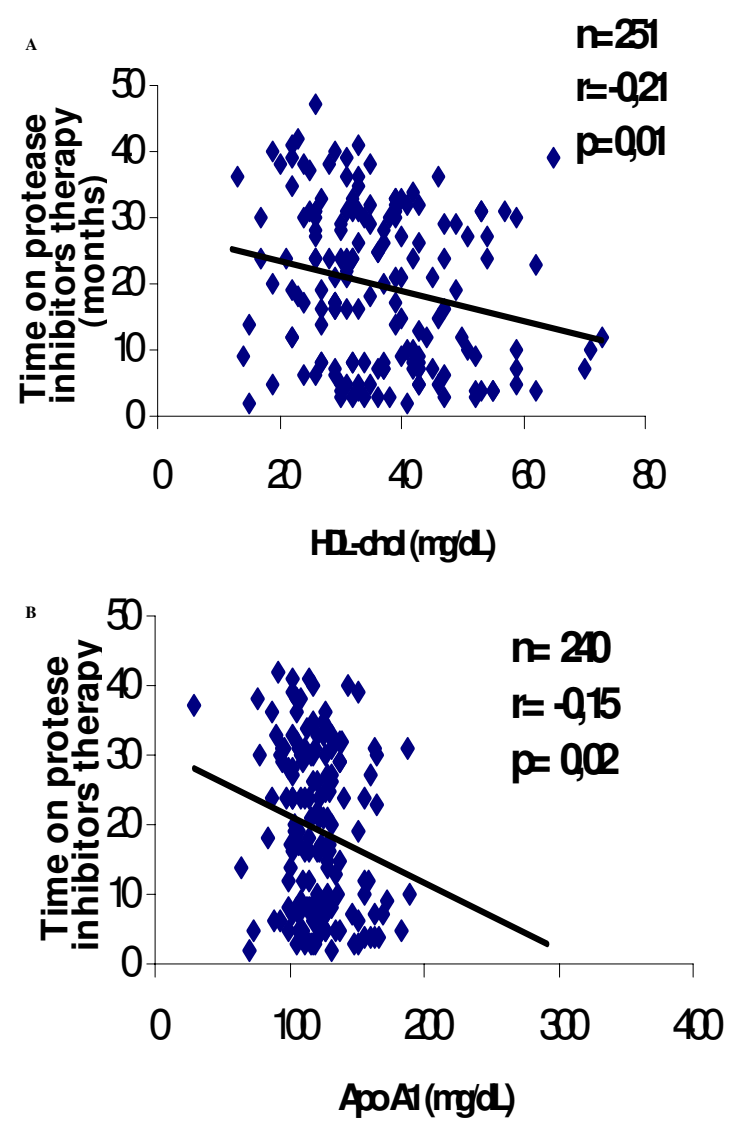

Figure 2

Correlations between time on protease inhibitor therapy and HDL-chol, (panel A) and Apo A I (panel B).

Although HIV infection itself has been associated with altered lipid metabolism, substantial evidence indicates a role for some protease inhibitors and reverse transcriptase inhibitors in causing metabolic complications [27-32]. Many adverse reactions can be attributed to protease inhibitors, however; because several treatments use drug association regimens, it is difficult to find out the exact causal connection [33].

Several reports have associated hypertriglyceridemia with the use of antiretroviral therapy $[6,8,30,33-37]$; however, the increase in triglyceride levels was also described in HIV+ patients before the utilization of HAART $[11,38]$. Hypertriglyceridemia was highly prevalent in our and other studies [6,11-13,36,38-43]. This may also be secondary to cytokine production. Cytokines have been shown to increase hepatic lipid synthesis and/or decrease levels of lipoprotein lipase, which results in slower 
clearance of circulating triglyceride-rich particles [44]. Grunfeld et al [44] found a highly significant positive correlation between interferon- $\alpha$ and triglyceride levels. In our study, hypertriglyceridemia was present in $46 \%$ percent of the HIV+ patients. Thirty-six percent of the patient's hyperlipoproteinaemia was due to types IV and IIb (Table 3). The origin of the hypertrygliceridemia could be an increased hepatic VLDL-TG secretion rate, with high availability of FFA to the liver, secondary to insulin resistance, common in these patients $[45,46]$. Seventy nine percent of our patients presented high plasma levels of FFA, corroborating with this metabolic state.

We did not find significant correlations between triglycerides and viral load [16], CD4 levels $[13,40]$ and the type of antiretroviral therapy [35], but we did find negative correlation between the duration of treatment with PI and HDL-chol $(\mathrm{p}=0.01)$.

Low HDL-Chol was one of the major findings in this Brazilian HIV+ population $(65 \%)$. These findings are in accordance with several authors $[13,35,42]$. Several metabolic processes may contribute to these low HDL levels: decrease in free cholesterol removal from cells, low cholesterol esterification rate and high cholesteryl ester transfer from HDL to apo-B containing lipoproteins [47].

Hypercholesterolemia was very prevalent in the dyslipidemic individuals described here: $58 \%$ are types IIa and IIb. Grunfeld et al.[44] didn't find significant differences in the cholesterol levels of patients affected by HIV: HIV+; HIV+ with AIDS or HIV negative, but Law et al. found raised cholesterol and triglyceride levels in patients receiving HAART, compared with patients not receiving HAART [10]. Our results are in agreement with Law's paper.

Grunfeld et al [39] showed a significant decrease in cholesterol levels in the HIV+ and HIV+ with AIDS patients, when compared to HIV- subjects. Shor-Posner et al [48] observed hypocholesterolemia (chol $<150 \mathrm{mg} / \mathrm{dL}$ ) in $41 \%$ of HIV+ and in $17 \%$ of HIV- patients. Christeff et al [40] reported decreased concentrations of cholesterol and phospholipids in HIV+ patients, except in those with low CD4 counting (400-150 cells $/ \mathrm{mm}^{3}$ ). In this study, $29 \%$ of the patients presented hypocholesterolemia. We found an inverse correlation between plasma cholesterol levels and the viral load.

The observed high frequency of hypercholesterolemia and hyperbetalipoproteinemia in HIV+ Brazilian patients were never reported previously (Table 1, Figure 1). Also analyzing the various patterns of the combined hyperlipidemia the most prevalent were alterations in TG plus HDL-chol and LDL-chol plus HDL-chol, respectively 35 and $32 \%$; total cholesterol plus TG and HDL-chol in 38\% and $11 \%$ of patients had four different lipidic parameters altered.

\section{Conclusion}

The high frequency of phenotypes IIb and IV found in the Brazilian HIV positive patients and the severity of the disturbances such as: hypercholesterolemia up to $672 \mathrm{mg} /$ $\mathrm{dL}$, hyperbetalipoproteinemia up to $227 \mathrm{mg} / \mathrm{dL}$, hypertriglyceridemia up to $1512 \mathrm{mg} / \mathrm{dL}$ and hypoalphalipoproteinemia below $13 \mathrm{mg} / \mathrm{dL}$, indicate the urgent need for their early diagnosis, the identification of the presence of other risk factors for CHD and, when needed, the prompt intervention on their lifestyle and/or drug treatment $[49,50]$.

\section{Competing interests}

The author(s) declare that they have no competing interests.

\section{Authors' contributions}

EMVA performed the biochemical analyses, data calculations and interpretation of results and helped to write the manuscript. ECF helped in the clinical trials and to write the manuscript. HCFO helped to write the manuscript. DOM participated in the clinical trial of HIV patients. LNC planned and coordinated the whole study, and helped to write the manuscript. All authors read and approved the final manuscript.

\section{Acknowledgements}

Financial support for the study was provided by Coordenadoria de Aperfeiçoamento de Pessoal de Ensino Superior - CAPES - and Fundo de Apoio ao Ensino e Pesquisa - FAEP/FCM. The authors are gratefull to Dr. Joyce M. Annichino-Bizzacchi-Director of Hemocentro-UNICAMP and Cleide Aparecida Moreira Silva (Statistical Research Commission of UNICAMP) for their excellent technical assistance.

\section{References}

I. Behrens G, Schmidt H, Meyer D, Stoll M, Schmidt RE: Vascular complications associated with use of HIV protease inhibitors [letter]. Lancet 1998, 35 I:1958.

2. Henry K, Melroe H, Huebsch J, Hermudson J, Levine C, Swensen L, Daley J: Severe premature coronary artery disease with protease inhibitors [letter]. Lancet 1998, 35 I:1328.

3. Gallet B, Pulik M, Genet P, Chedin P, Hiltgen M: Vascular complication associated with use of HIV protease inhibitors [letter]. Lancet 1998, 35 I:1958-1959.

4. Vittecoq D, Esacaut L, Monsuez JJ: Vascular complication associated with use of HIV protease inhibitors [letter]. Lancet 1998, $351: 1959$.

5. Karmochkine M, Raguin G: Severe coronary artery disease in a Young HIV-infected man with no cardiovascular risk factor who was treated with Indinavir [letter]. AIDS 1998, I 2:2499.

6. Behrens G, Dejam A, Schmidt H, Balks HJ, Brabant G, Korner T, Stoll $M$, Schmidt RE: Impaired glucose tolerance, beta cell function and lipid metabolism in HIV patients under treatment with protease inhibitors. AIDS 1999, 13:F63-F70.

7. Jütte A, Schwenk A, Franzen C, Römer K, Diet F, Diehl V, Fätkenheuer G, Salzberger B: Increasing morbidity from myocardial infarction during HIV protease inhibitor treatment. AIDS 1999, 13:1796-1797. 
8. Sereger S, Bogner JR, Walli R, Loch O, Goebel FD: Hyperlipidemia under treatment with protease inhibitors. Infection 1999, 27:77-8I.

9. Sullivan AK, Nelson MR: Marked hyperlipidaemia on ritonavir therapy. AIDS 1997, I I:938-939.

10. Law M, Friis-Moller N, Weber R, Reiss P, Thiebaut R, Kirk O, d'Armino Monforte A, Pradier C, Morfeldt L, Calvo G, El-Sadr W, De Wit S, Sabin CA, Lundgren JD: Modelling the 3-year risk of myocardial infarction among participants in the Data Collection on Adverse Events of Anti-HIV Drugs (DAD) study. HIV Med 2003, 4: I- 10 .

II. Grunfeld C, Kotler DP, Hamadeh R, Tierney A, Wang J, Pierson RN: Hypertriglyceridemia in the acquired immunodeficiency syndrome. AmJ Med 1989, 86:27-3I.

12. Hellerstein MK, Grunfeld $C$, Wu K, Christiansen M, Kaempfer S, Kletke C, Shackleton CHL: Increased de novo hepatic lipogenesis in human immunodeficiency virus infection. J Clin Endocrinol Metab 1993, 76:559-565.

13. Constans J, Pelegrin JL, Peuchat E, Dumon MF, Pellegrin I, Sergeant C, Simonoff M, Brossard G, Barbeau P, Fleury H, Clerc M, Leng B, Conri $\mathrm{C}$ : Plasma lipids in HIV-infected patients: a prospective study in 95 patients. Eur J Clin Invest 1994, 24:4 I6-420.

14. Sposito AC, Caramelli B, Sartori AM, Ramires JAF: The lipoprotein profile in HIV infected patients. Braz J Infect Dis 1997, I:275-283.

15. Sellmeyer DE, Grunfeld C: Endocrine and metabolic disturbances in human immunodeficiency virus infection and the Acquired Immune Deficiency Syndrome. Endocr Rev 1996, 1 7:518-532.

16. Hadigan C, Miller K, Corcoran C, Anderson E, Basgoz N, Grinspoon $S$ : Fasting hyperinsulinemia and changes in regional body composition in human immunodeficiency virus-infected women. J Clin Endocrinol Metab 1999, 84:1932-1937.

17. Safrin S, Grunfeld C: Fat distribution metabolic changes in patients with HIV infection. AIDS 1999, I 3:2493-2505.

18. U.S. Agency for International Development [http:// www.usaid.gov/pop health/aids/Countries/lac/brazilbrief.pdf]

19. Caramelli B, Bernoche Cysm, Sartori AMC, Sposito AC, Santos RD, Monachini MC, Strabelli T, Uip D: Hyperlipidemia related to the use of HIV-protease inhibitors: natural history and results of treatment with fenofibrate. Braz J Infect Dis 200I, 5:332-338.

20. Gillery P, Arthuis P, Cuperlier C, Circaud R: Rate nephelometric assay of serum lipoprotein(a). Clin Chem 1993, 39:503-508.

21. Chapman J, Estupinan J, Asherov A, Goldfarb LG: A simple and efficient method for apolipoprotein $E$ genotype determination. Neurology 1996, 46: I484-|485.

22. Fredrickson DS, Levy RS, Lees RS: Fat transport in lipoproteins an integrated approach to mechanisms and disorders. $N$ Engl J Med I967, 276:273-28I.

23. National Cholesterol Education Program: Executive Summary of the Third Report of the National Cholesterol Education program (NCEP) Expert Panel on Detection, Evaluation and Treatment of High Blood Cholesterol in Adults (Adult treatment Panel III). JAMA 200I, 285:2486-2497.

24. Castelli WP: The triglyceride issue: a view from Framingham. Am Heart J 1986, I I 2:432-437.

25. Schmidt HH, Behrens G, Genschel J, Stoll M, Dejam A, Haas R, Mans MP, Schmidt RE: Lipid evaluation in HIV-I-positive patients treated with protease inhibitors. Antivir Ther 1999, 4: 163-170.

26. Mauss S, Stechel J, Willers R, Schmutz G, Berger F, Richter WO: Differentiating hyperlipidaemia associated with antiretroviral therapy. AIDS 2003, I 7:189-194.

27. Lenhard JM, Croom DK, Weiel JE, Winegar DA: HIV Protease inhibitors stimulate hepatic triglyceride synthesis. Arterioscler Thromb Vasc Biol 2000, 20:2625-2629.

28. Stein JH: Dyslipidemia in the era of HIV protease inhibitors. Prog Cardiovasc Dis 2003, 45:293-304.

29. Stricker RB, Goldberg B: Fat accumulation and HIV-I protease inhibitors [letter]. Lancet 1998, 352:1392.

30. Carr A, Samaras K, Burbon S, Law M, Freund J, Chisholm DJ, Cooper DA: A syndrome of peripheral lipodystrophy, hyperdipidaemia and insulin resistance in patients receiving HIV protease inhibitors. AIDS 1998, 12:F5I-F58.

31. Gagnon A, Angel JB, Sorisky A: Protease inhibitors and adipocyte differentiation in cell culture [letter]. Lancet 1998, 352:1032.

32. Miserez AR, Muller PY, Spaniol V: Indinavir inhibits sterol-regulatory element-binding protein-Ic-dependent lipoprotein lipase and fatty acid synthase gene activations. AIDS 2002 , I 6: I587- 1594.

33. Bonfanti P, Valsecchi L, Parazzini F, Carradori S, Pusterla L, Fortuna $P$, Timillero L, Alessi F, Ghiselli G, Gabbuti A, Di Cintio E, Martinelli C, Faggion I, Landonio S, Quirino T: Incidence of adverse reaction in HIV patients treated with protease inhibitors: A cohort study. Coordinamento Italiano Studio Allergiae Infezione da HIV (CISAI) Group. J Acquir Immune Defic Syndr 2000, 23:236-245.

34. Carr A, Samaras K, Chisholm DJ, Cooper DA: Pathogenesis of HIV-I protease inhibitor-associated peripheral lipodystrophy, hyperlipidaemia, and insulin resistance. Lancet 1998 , 351 : $1881-1883$.

35. Carr A, Samaras K, Thorisdottir A, Kaufmann GR, Chisholm DJ, Cooper DA: Diagnosis, prediction, and natural course of HIVI protease-inhibitor-associated lipodystrophy, hyperlipidaemia, and diabetes mellitus: a cohort study. Lancet 1999, 353:2093-2099.

36. Walli R, Herfort $O$, Michl GM, Demant T, jäger H, Dieterle C, Bogner JR, Landgraf R, Goebel FD: Treatment with protease inhibitors associated with peripheral insulin resistance and impaired oral glucose tolerance in HIV-I infected patients. AIDS 1998 , I2:FI67-FI73.

37. Jain RG, Furfine ES, Pedneault L, White AJ, Lenhard JM: Metabolic complications associated with antiretroviral therapy. Antiviral Res 2001, 51:151-177.

38. Thiébaut R, Dabis F, Malvy D, Jacqmin-Gadda H, Mercié $P$, Valentin VD, Daucourt V: Serum triglycerides, HIV infection, and highly active antiretroviral therapy, Aquitaine cohort, France, I996 to 1998. Groupe d'Epidemiologie Clinique du Sida en Aquitaine (GECSA). J Acquir Immune Defic Syndr 2000, 23:26 I-265.

39. Grunfeld C, Pang M, Doerrler W, Shinegaga JK, Jensen P, Feingold KR: Lipids, lipoproteins, triglyceride clearance, and cytokines in Human Immunodeficiency Virus Infection and the Acquired Immunodeficiency Syndrome. J Clin Endocrinol Metab 1992, 74: 1045-1052.

40. Christeff N, Lortholary O, Casassus P, Thobie N, Dalle MT, Veyssier $P$, Guillevin L, Nunez EA: Serum lipid concentration with reference to the clinical and immunological status of HIV infected men. Ann Med Interne 1995, I 46:490-495.

4I. Seidlin M, Lambert JS, Dolin R, Valentine FT: Pancreatitis and pancreatic dysfunction in patients taking dideoxyinosine. AIDS 1992, 6:83|-835.

42. Zangerle R, Sarcletti M, Gallati H, Reibnegger G, Wachter H, Fuchs $\mathrm{D}$ : Decreased plasma concentration of HDL-cholesterol in HIV-infected individuals are associated with immune activation. J Acquir Immune Defic Syndr 1994, 7: I I 49- I I 56.

43. Fernández-Miranda C, Pulido F, Carrilo JL, Larumbe S, Gomez Izquierdo T, Ortuño B, Rubio R, Palacio A: Lipoprotein alterations in patients with HIV infection: relation with cellular and humoral immune markers. Clin Chim Acta 1998, 274:63-70.

44. Grunfeld C, Kotler DP, Shinegaga JK, Doerrler W, Tierney A, Wang $\mathrm{J}$, Pierson RN, Feingold KR: Circulating interferon- $\alpha$ levels and hypertrigliceridemia in the Acquired Immunodeficiency Syndrome. Am J Med 1991, 90:154-162.

45. Cheng M, Chen S, Schow SR, Manchen VP, Spevak WR, Cristobal CP, Shi S, Macsata RW, Lum RT, Goldfine ID, Keck JG: In vitro and in vivo prevention of HIV protease inhibitor-induced insulin resistance by a novel small molecule insulin receptor activactor. J Cell Biochem 2004, 92: I 234- I 245.

46. Hommes MJ, Romjin JA, Endert E, Eeftinck Schattenkerk JK, Sauerwein HP: Insulin sensitivity and insulin clearance in human immunodeficiency virus-infected men. Metabolism 1991, 40:65I-656.

47. Brites FD, Bonavita CD, De Geitere C, Cloës M, Delfly B, Yael MJ, Fruchart J, Wikinski RW, Castro GR: Alterations in the main steps of reverse cholesterol transport in male patients with primary hypertriglyceridemia and low HDL-cholesterol levels. Atherosclerosis 2000, I 52:181-192.

48. Shor-Posner G, Basit A, Lu Y, Cabrejos C, Chang J, Fletcher M, Mantero-Atienza $\mathrm{E}$, Baum MK: Hypocholesterolemia is associated with immune dysfunction in early human immunodeficiency virus - I infection. Am J Med 1993, 94:515-5I9.

49. Dubé MP, Stein JH, Aberg JA, Fichtenbaum CJ, Gerber JG, Tashima $\mathrm{KT}$, et al:: Guidelines for evaluation and management of dyslipidemia in human immunodeficiency virus (HIV)-infected adults receiving antiretroviral therapy: recommendations of 
the HIV Medical Association of the Infectious Disease Society of America and the Adult AIDS Clinical Trials Group. Clin Infect Dis 2003, 37:613-627.

50. Grinspoon S, Carr A: Cardiovascular risk and body-fat abnormalities in HIV-infected adults. N EnglJ Med 2005, 352:48-62.

\section{Pre-publication history}

The pre-publication history for this paper can be accessed here:

http://www.biomedcentral.com/1471-2334/5/47/prepub
Publish with Bio Med Central and every scientist can read your work free of charge

"BioMed Central will be the most significant development for disseminating the results of biomedical research in our lifetime. " Sir Paul Nurse, Cancer Research UK

Your research papers will be:

- available free of charge to the entire biomedical community

- peer reviewed and published immediately upon acceptance

- cited in PubMed and archived on PubMed Central

- yours - you keep the copyright

Submit your manuscript here:

http://www.biomedcentral.com/info/publishing_adv.asp 